\title{
ЭКОНОМИЧЕСКАЯ ПРЕСТУПНОСТЬ И УГОЛОВНАЯ ПОЛИТИКА
}

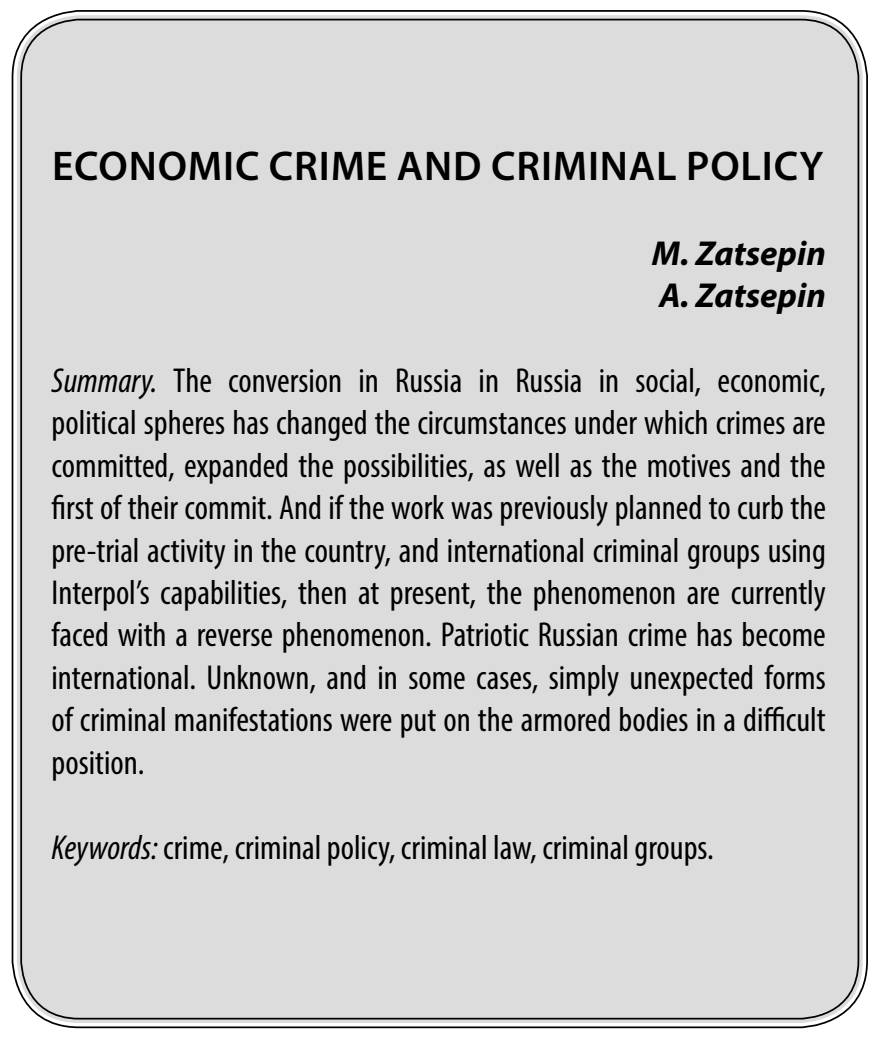

$\Pi$ роводимые в России меры по борьбе с отрицательным явлением - преступностью дают определенные положительные результаты, однако нельзя не отвечать на вопросы о том, почему дает сбои «правоохранительный механизм» - законодательство (и не в последнюю очередь уголовное), а также правоприменительная деятельность системы правоохранительных органов.

Используя ситуацию, преступные организации распространили свою деятельность через национальные границы. Это достигается как непосредственным образом, так и созданием международных групп, цель которых в материальном обеспечении друг друга и технической поддержке. Непосредственным следствием является не только расширение масштабов трансграничных преступных операций, но и общее повышение их эффективности. Интернационализация экономической преступности проявляется в возникновении крупных мировых рынков, на которых осуществляется обмен различными товарами и услугами.[3]

Серьезную тревогу представляет активное проникновение преступных групп в сферу законной предпринимательской деятельности как на национальном, так
Зачепин Михаил Николаевич

Д.ю.н., профессор, Заслуженный юрист Российской Федерачии, Аналитик управления научных исследований и международного сотрудничества ургюУ; член Российской криминологической ассочиачии mnz-1958@mail.ru

Зачепин Александр Михайлович

К.ю.н., дочент, УрГЮУ; виче-президент Российской криминологической ассоциации tp0507@ya.ru

Аннотация. Происходящие в России преобразования в социальной, экономической, политической сферах изменили обстоятельства, при которых совершаются преступления, расширили возможности, а также мотивы и причины их совершения. И если ранее планировалась работа по пресечению преступной деятельности на территории страны, а международных преступных групп с использованием возможностей Интерпола, то в настоящее время правоохранительные органы столкнулись с обратным феноменом. Отечественная российская преступность стала интернациональна. Неизвестные, а в ряде случаев просто неожиданные формы преступных проявлений поставили правоохранительные органы в сложное положение.

Ключевые слова: преступность, уголовная политика, уголовный закон, преступные группы.

и на международных уровнях. Процесс этот вызван различными причинами и преследует разные цели. Законная предпринимательская деятельность служит удобным прикрытием для масштабных незаконных операций. Ситуация усугубляется тем, что путем инфильтрации в законные государственные и бизнес организации, совместные корпорации преступники размещают существенную часть незаконных доходов. С учетом кратко изложенных обстоятельств необходимо предпринимать согласованные, многосторонние усилия правоохранительных органов по выявлению и прогнозированию развития преступности в экономической сфере для разработки эффективных мер борьбы с ними. Для нашей страны это означает, прежде всего, совершенствование уголовной политики, которая бы в полной мере учитывала социальные реальности и потребности уголовного закона.[5]

Уголовный закон использует в борьбе с преступлениями свои специфические средства. Он предусматривает за совершение преступлений применение строгих мер уголовного наказания, тем самым запрещает разнообразные формы антиобщественного поведения. Уголовно-правовой запрет исходя из практики по характеру воздействия на общество имеет предупреди- 
тельное воздействие на большинство граждан, которые не совершают преступлений не потому, что бояться наказания, а в силу нравственных установок понимания того, что преступление противоречит их интересам и общества или наличие угрозы в уголовном законе недостаточно и те граждане, которые не совершают преступлений именно вследствие страха перед уголовным наказанием.[6]

Проводимая уголовная политика оказывает свое воздействие на поведение не всех членов общества, а некоторой его части и такое воздействие нельзя не преувеличивать или преуменьшать. Разумеется, сами граждане, не отдалены друг от друга непреодолимым барьером и границы между ними весьма подвижны. Факторы, которые способны увеличивать или уменьшать долю законопослушных граждан - принцип неотвратимости наказания за совершенные преступления и справедливости, которые должны лежать в основе построения уголовного закона. Резервы этих факторов существуют не только в отношении деятельности правоохранительных органов, но и в самом содержании уголовно-правовых норм, уголовной политике.

В России растет количество уголовных дел в отношении представителей бизнеса, в которых выполненные и принятые заказчиком работы вменяют в качестве ущерба. Помимо общей фабулы, подобные кейсы объединяют еще несколько моментов - истории силового давления разворачивают вокруг госконтрактов, правоохранители и суды поддерживают чиновников, а коммерсантов годами держат в СИЗО. [2]

Развенчать распространенный миф на жестокость и кару как лучшее средство в борьбе с преступностью не получается и по сей день. Социологические исследования показывают о том, что на вопрос о необходимо ли меры уголовной ответственности сделать более суровыми, большинство отвечают утвердительно. В СССР усиление борьбы с преступностью не означало обязательного усиления наказания, напротив, в отношении преступлений, не представляющих большой общественной опасности, совершенных впервые лицами, находящимися в системе социально полезных связей, успех заключался в применении мер наказания, не связанного с лишением свободы, с изоляцией осужденного от семьи и общества.

На вопрос, сформулированный в начале статьи как уменьшить влияние негативных сторон на состояние преступности, поставим несколько иначе - для кого адресована уголовная политика и как ее часть уголовный закон? Ответ вроде как очевиден - на то и уголовный закон, что он рассчитан на людей, совершающих преступления. Исследования показывают: что не только на них, но и на честных, сознательных и законопослуш- ных граждан, т.к. некоторые положения уголовного закона обращается к честным, законопослушным гражданам и нет нужды доказывать профилактическое воздействие как конституционных, так и уголовно-правовых норм в борьбе с преступностью.

Профилактическая роль уголовного закона заключается не столько в том, что угрозой наказания он побуждает воздержаться от совершенствования преступления, но и в том, что он стимулирует к отказу от преступления, где средством к правомерному поведению выступает не угроза наказания, а перспектива освобождения от ответственности. Оценку уголовной политики нужно дифференцировать по содержанию, выделяя конкретные формы, интенсивность, механизмы, и по ее последствиям, выявляя цели, достижению которых способствовали программы. При этом в программах борьбы с насильственной преступностью следует сохранять, а иногда усиливать наказание как способа достижения цели, а подход к преступлениям в экономической сфере, непредумышленным преступлениям должен быть иным и крайне осторожно подходить к расширению и усилению уголовной ответственности. Теоретически, да и практически вполне возможно привлечь к уголовной ответственности большую часть предпринимателей и участников экономической деятельности, превышающих служебные полномочия, искать лиц виновных в принятии «неправильных» решений. Последствия такой уголовной политики приводят к росту осужденных при уже существующем уровне криминализации и повышают количественные показатели рецидива, способствуют дальнейшему сплочению лиц, склонных к совершению преступления. Иногда, к сожалению, расширение репрессии к субъектам экономической деятельности (предпринимателям) нередко приводят к наказанию аутсайдеров, случайных, а не опасных преступников. При усилении дифференцирующей функции уголовной политики в экономической сфере целесообразно ограничить репрессии, а точнее, их оптимизировать, сочетать с расширением возможности процессуального усмотрения в сторону смягчения наказания либо освобождения от ответственности. Это должно обеспечиваться профилактическим направлением уголовной политики, стремлением к уменьшению преступлений в сфере экономической деятельности и позитивной социальной жизни бизнеса.

В науке уголовного права довольно распространено мнение, что предупредительному воздействию необходимо подвергать лиц лиц, склонных к совершению преступлений. Это заблуждение обязано своим происхождением в СССР, в рамках общепредупредительного воздействия и ограничивалось лишь действием угрозы уголовным наказанием. 
До настоящего времени механизм устрашающего воздействия уголовного наказания остается одной из удивительных загадок цивилизации. История знает множество часто взаимоисключающих опытов профилактического воздействия на человека: от почти полного отказа от уголовного наказания до признания страха перед расстрелом панацеей от всех болезней общества. Ни один из этих опытов не увенчался полным успехом потому как, средства никогда не соответствовали поставленным целям, от недостижимости этого соответствия вообще. Даже в атмосфере постоянного страха потерять свободу и саму жизнь, не удавалось одержать победу над преступностью, сколь бы суровым и неотвратимым ни было наказание, как бы горячо ни желало общество устрашить всех потенциальных преступников - это никогда сделать не удается.

Положение осложняется еще и тем, что уголовная политика, призванная вырабатывать основные задачи, принципы, направления и цели уголовно-правового воздействия на преступность, а также средства и дости- жения, находятся сейчас в постоянной динамике. Нет ясности в том, в каком направлении и в каких формах пойдет дальнейшее общественное развитие. Не приняты в полной мере к исполнению программы борьбы с преступностью и не завершена реформа уголовного законодательства. Не менее важное то, что стала встречать все большее сопротивление имевшая силу тенденция к гуманизации уголовной репрессии, в связи с не решением проблем уголовного законодательства и существующие в общественном мнении противоречия.[1]

Исследования показывают, что общественное мнение, выступая в целом за расширение уголовной ответственности (хотя и не формулируя конкретных предложений на этот счет) и за ужесточение санкций в рамках действующего законодательства, одновременно склоняется к тому, что эффективность лишения свободы невысока и отбывание наказания в местах лишения свободы в большинстве случаев не достигает цели и оборачивается дополнительными расходами для государства.

\section{ЛИТЕРАТУРА}

1. Госдума начала декриминализацию // 26.02.2016. https://pda.pravo.ru/news/view/126621/.

2. Госзаказ как дорога за решетку: Борис Титов бьет тревогу и меняет законы. 25.11.2020. https://pasmi.ru/archive/291463/.

3. Молдавская схема по российскому госзаказу: как дела «Ландромата» выводят ФСБ и ЦБ // 18.08.2020. https://pasmi.ru/archive/278676/; «0тмыли миллиарды долларов»: богатых россиян обвинили в распространении коррупции в Европе https://pasmi.ru/archive/294486/.

4. Новый обзор КС: правовые позиции об определенности уголовного закона // 13.11.2020. https://pravo.ru/story/228600/.; Верховный суд выпустил четвертый обзор практики в 2020 году. 21.12.2020. https://pravo.ru/story/228600/.

5. Предпринимателям надо объединяться, а УК изменять: как защитить бизнес в России //19.06.2019. https://pravo.ru/story/212411/.; В Екатеринбурге впервые за пять лет вырос уровень преступности // https: www.znak.com/2020-02-18/.

6. Согласительный» уклон: почему в России не работает уголовное правосудие // 17.12.2017. https://pravo.ru/opinion/view/142449/.; За что сажают юристов: уголовные дела и способы снижения рисков 02.03.2021. https://pravo.ru/opinion/229851/.

7. Суддеп опубликовал статистику по судам и судимости за полгода // 16.10.2020. https://pravo.ru/news/226664/.; Взятки на миллиарды: прокуратура подсчитала ущерб от коррупции // 09.03.2021. https: //pasmi/ru/archive/ 